as is Modood. Tighter editing would have helped here, and also on those occasions where Browning makes a comparison between Collingwood and another thinker without following it up in detail. There is sometimes a tendency to juxtapose Collingwood with other thinkers (whether Lyotard or Rawls) without it really being clear what the point of the exercise is, other than that it might be interesting that there are similarities. At the risk of sounding ungrateful, a slightly longer book, more tightly edited and with space to develop some of its themes at slightly greater length would have been more satisfying. But if ever called upon to recommend a book that deals sensitively and sympathetically with Collingwood's philosophy in relation to politics, philosophy and theory and practice, I shall not hesitate (and neither should you) to recommend this volume.

James Connelly Southampton Institute, UK.

\title{
The Philosopher and His Poor
}

Jacques Rancière, edited and with an introduction by Andrew Parker, translated by John Drury, Corinne Oster and Andrew Parker Duke University Press, Durham \& London, 2004, xxvi+247pp. ISBN: 0822332744.

Contemporary Political Theory (2006) 5, 217-219. doi:10.1057/palgrave.cpt.9300223

Why have so few philosophers been democrats?, asks Jacques Derrida in Voyous (2003). In The Philosopher and His Poor, first published in French 20 years prior to Voyous (1983), and now available in English translation, Jacques Rancière sketches an answer to the same question. The philosopher divides himself from his poor, the thinker from the labourer. Philosophy is founded in a principle of distinction that is maintained even by the author of Distinction; from Plato to Bourdieu, social theory abolishes politics by refusing to recognize the possibility that the shoemaker might also take to the public stage. Those familiar with Rancière's work will recognize here an early outline of political themes dealt with in more recent books such as The Shores of Politics and Disagreement. The Philosopher and His Poor will be of value to such readers on more than merely genealogical grounds, however; in the reading of Plato which opens the book lies the common ground for the author's political and aesthetic writings, whose trajectories might appear to have diverged somewhat in recent years. For the same reason, those new to Rancière will find this a helpful introduction. 
As with Rancière's political writings, the book makes most sense read backwards: through considering the contemporary problem to which the text is a response. In this case a polemic against Bourdieu is interwoven with an attack on sociology as what the author will call 'metapolitics' in Disagreement, an alleged reversal of Platonism whose scientific pretensions perpetuate the philosophical vision of justice as a naturalized distribution of roles. Having given up on the science of truth, sociology becomes the inventory of falsehoods; but in distinguishing between the myths believed by the people and its own capacity to analyse them it needs to maintain discursive proprieties. On Rancière's rather violent reading, in Bourdieu's case this leads to a philosophy of education in which each is to be educated according to the appropriate cultural norms for their class. Denouncing the school as a form of social control leaves only the possibility of reconciliation to a cultural and educational inferiority assigned as if by necessity.

What Rancière sees in the intellectual's respect for the worker, in the hymn to the masses sung by the modern thinker, is the message: know your place. What threatens the sociologist, as much as the ancient philosopher, is the potential equality of common opinion with their own forms of knowledge, which is played out in their work as the abolition of politics. Sartre's justification of the Communist Party line, Rancière suggests in a companion chapter to the Bourdieu study, is the erection of that wall between the intellectual and the worker which he claims to abolish; in his paean to the worker he refuses them the right to the aesthetic and intellectual freedom he may enjoy. As for Plato, so for Sartre, a worker is a worker is a worker.

Except when the worker is failing to be a proletarian. The central section of the book traces these sociological contradictions back to the work of Marx, and it is hard not to see this as part of Rancière's continuing attempt to unravel his early association with Althusser, who like Marx wishes for 'a philosopher who is no longer a philosopher and a worker who is no longer a worker: a scientist and a proletarian' (p. 76). The science of materialism writes the history of the world as stages of production, but the proletariat will never act out its role in the manner the dramatist has intended; nor, indeed, will the bourgeoisie. The history of labour is doubled by a postponed revolutionary justice: both the flawed justice of the here and now and the communism of the auto-didact brotherhood of the artisans are anathema to Marx. In his portrait of the 'philosopher-king of bohemia' (p. 102), Rancière effectively skewers the posturing of any self-proclaimed aesthetic or political radical. His account of Marx and Engels is acute but also very funny, as he has an unerringly sharp eye for pomposity: 'the basic risk that menaces revolutionary action is not the threat of defeat or death in combat, but the threat of comedy' (p. 111). Or put more crudely, one of the virtues of Rancière's work is his excellent bullshit detector. 
That the distribution of roles on which philosophical and sociological accounts of justice depend is always threatened by the production of appearances, the power to reconfigure the common order, is argued in the first section of the book. This sheds helpful light on Rancière's later account of aesthetics as the partage du sensible, and helps us establish why in The Names of History he proposes a poetics of knowledge. The exclusion of the artists from the Republic answers not to a moral imperative, but to the need for philosophy to 'trace the circle of its own autonomy [...] through an arbitrary discourse on nature and nobility' (p. 53). Plato, like Marx, is for Rancière a somewhat ambivalent figure, whose writings exhibit a kind of paradoxical honesty ('extraordinary frankness' (p. 52)) in revealing what they demand should be concealed. In this case, his writings reveal that the philosophical fiction of nature requires the distinction between true and false fictions, and sets in motion the social and discursive hierarchies which are Rancière's target throughout.

Both the delay in publication of an English edition, and its unusual methods, require that The Philosopher and His Poor comes swathed in paratexts: layers of prefaces, introductions, conclusions. Many of these are as interesting as the bulk of the work, and include useful reflections by Rancière on his intellectual itinerary. In his own introduction, Andrew Parker reminds us of Rancière's interest in Virginia Woolf's work as a model for historical narrative. But it should also be clear from the challenge levelled at philosophy in the book that this needs to be recognized as a text which is not exhausted in the communication of its ideas, but which might equally produce pleasure. Or in other words, this is a stylish, witty, and provocative book, which is also an astute work of profound political realism.

Alex Thomson University of Glasgow, UK. 